\title{
Energy expenditure and food consumption by breeding Cape gannets Morus capensis
}

\author{
N. J. Adams ${ }^{1}$, R. W. Abrams ${ }^{1 *}$, W. R. Siegfried ${ }^{1}$, K. A. Nagy ${ }^{2}$, I. R. Kaplan ${ }^{3}$ \\ ${ }^{1}$ Percy FitzPatrick Institute of African Ornithology, University of Cape Town, Rondebosch, 7700, South Africa \\ ${ }^{2}$ Laboratory of Biomedical and Environmental Sciences, University of California, Los Angeles, California 90024, USA \\ ${ }^{3}$ Department of Earth and Space Sciences, University of California, Los Angeles, California 90024, USA
}

\begin{abstract}
Gannets (genus Morus) are piscivorous seabirds with a breeding distribution restricted to the cool to temperate waters of the mid latitudes. Field metabolic rates of breeding Cape gannets $M$. capensis and their chicks were measured using doubly labelled water. Energy expenditures of adults incubating or brooding chicks at the nest were $2090 \mathrm{~kJ} \mathrm{~d}^{-1}(24.2 \mathrm{~W}, 2.9 \times$ basal metabolic rate, BMR). Metabolic rates of adults at sea were $4670 \mathrm{~kJ} \mathrm{~d}^{-1}(54.1 \mathrm{~W}, 6.5 \times$ BMR). Overall field metabolic rates (FMRs), assuming birds spend half their time on land and half at sea, were $3380 \mathrm{~kJ} \mathrm{~d}^{-1}(39.1 \mathrm{~W}, 4.7 \times$ BMR). Relative FMRs of adult birds were high compared with those of most other volant seabirds and approach those of high latitude seabirds that use mainly flapping flight, including the closely related northern gannet $M$. bassanus. Such high values probably reflect the high energy cost of sustained flapping flight and the plunge-diving foraging of gannets while at sea. Food consumption rates, calculated on the basis of the chemical composition of Cape anchovy Engraulis capensis and energy expenditure determined from $\mathrm{CO}_{2}$ production, averaged $691 \mathrm{~g} \mathrm{~d}^{-1}$ for incubating or brooding adults and $521 \mathrm{~g} \mathrm{~d}^{-1}$ for chicks. A pair of gannets successfully raising a chick would consume $246 \mathrm{~kg}$ of fish over the course of a breeding season. Total annual consumption of the gannet population in the southern Benguela upwelling system amounted to no more than $23400 \mathrm{t}$. Of this $9000 \mathrm{t}$ was accounted for by the commercially important anchovy. This probably represents no more than $1 \%$ of the total adult spawner biomass of this fish in the region.
\end{abstract}

\section{INTRODUCTION}

Seabirds are conspicuous top predators in marine ecosystems. Their presumed importance as consumers has stimulated studies of their energy budgets and food consumption to assess their potential impact in such systems (Wiens \& Scott 1975, Furness \& Cooper 1982, Croxall 1987). The difficulty of observing these birds at sea, offset by their often easy accessibility at the nest during breeding, has made the doubly labelled water (DLW) technique a powerful toal in assessing energy costs and budgets of individual species (Nagy et al. 1984, Gabrielsen et al. 1987, Nagy 1987, Obst et al. 1987). Such studies have allowed refinement of population food consumption models previously based on extrapolations of laboratory measurements of metabolism.

Because many seabirds have long breeding seasons,

\footnotetext{
- Present address: 40 Hitching Post, Glen Cove, New York 11542, USA
}

foraging costs of adults attending chicks are liable to form a significant portion of the annual energy budget (Furness \& Cooper 1982). Field metabolic rates (FMRs) of seabirds, determined using the DLW technique, are closely correlated with body mass (Nagy 1987). However, flight behaviour and the aerodynamic properties of different species of seabirds may have a considerable influence on energy costs, in particular of foraging (see review by Birt-Friesen et al, 1989). For example, the very low relative energy costs of foraging by albatrosses (Adams et al. 1986, Costa \& Prince 1987, Pettit et al. 1988) are consistent with their highly developed behavioural and morphological adaptations for economical flight. Although lower than calculated from published models (e.g. Tucker 1973), energy costs of foraging of the highly volant Wilson's storm-petrel Oceanites oceanicus (Obst et al. 1987), which engages in long periods of flapping flight, are considerably higher than albatrosses. The FMRs of least auklets Aethia pusilla, and common diving-petrels Pelecanoides urinatrix and South Georgia diving-petrels $P$. 
urinatrix, which combine flapping flight with pursuit diving, are similarly high (Roby \& Ricklefs 1986). Gannets and boobies (Family: Sulidae) are large, active, volant foragers in temperate and tropical waters (Nelson 1978). Recent work on the northern gannet Morus bassanus indicates that its FMRs are the highest yet measured for seabirds (Birt-Friesen et al. 1989). We present here measurements of FMRs of breeding Cape gannets Morus capensis which, in contrast to northern gannets, breed and forage in an area characterized by high levels of insolation (Cooper \& Siegfried 1976 , Nelson 1978). Measurements of the FMRs of adults are combined with energy costs of chick maintenance and growth to estimate total food consumption during breeding.

Cape gannets are confined largely to the Benguela Upwelling system off the southwestern coast of southern Africa, an area that also supports a large purse-seine fishery. Both gannets and the fishery may take the same prey, particularly Cape anchovy Engraulis capensis and pilchard Sardinops ocellatus (Berruti 1987, Berruti \& Colclough 1987) and such consumption estimates are a necessary step in assessing the degree of competition between these 2 consumer groups.

\section{MATERIALS AND METHODS}

Cape gannets resident at Bird Island, Lambert's Bay $\left(32^{\circ} 05^{\prime} \mathrm{S}, 18^{\circ} 17^{\prime} \mathrm{E}\right)$, South Africa, were studied during the breeding season 1981-82. Metabolic rates $1 \mathrm{CO}_{2}$ production) and water-flux rates were measured using doubly labelled water (DLW; Lifson \& McClintock 1966, Nagy 1980, Nagy \& Costa 1980) in incubating adults ( $\mathrm{n}=11$ ), adults attending large chicks $(\mathrm{n}=10)$, and in the chicks themselves $(n=6)$. Adults were given intra-muscular injections of $0.50 \mathrm{ml}$ water containing 45 atom- $\%{ }^{18} \mathrm{O}$ and 48 atom- $\%{ }^{2} \mathrm{H}$. At least $2 \mathrm{~h}$ later, blood samples (ca $2 \mathrm{ml}$ ) were taken from a brachial vein, and birds weighed and returned to their nests. Chicks were injected with either 0.15 or $0.25 \mathrm{ml}$ of DLW, depending on body mass. Some measurement intervals covered exclusively on- or off-nest periods. Birds sampled over off-nest periods were captured as they changed incubation or guard shifts, injected, and then held for the $2 \mathrm{~h}$ equilibration period before being bled and then released. Adult birds were recaptured on regular checks of study nests conducted throughout the day. Cape gannets are diurnally active, rarely returning to the nest after dusk. On recapture birds were bled and reweighed up to twice. Chicks (estimated age 19 to $45 \mathrm{~d}$ ) remained at the nest and were bled $21 \mathrm{~h}$ to $40 \mathrm{~h}$ after initial equilibration and reweighed. An additional 8 birds not used for doubly labelled water measure- ments were bled and the samples measured for background levels of heavy isotopes.

Isotope concentrations in water distilled from blood samples were measured by Global Geochemistry Corporation, Canoga Park, California, USA. For birds recaptured more than once we used only the initial and final blood sample to determine rates of $\mathrm{CO}_{2}$ production and water flux. Using the $\mathrm{CO}_{2}$ equilibration technique, ${ }^{18} \mathrm{O} /{ }^{16} \mathrm{O}$ ratios in the blood were assessed by isotope ratio-mass spectrometry, as were ${ }^{2} \mathrm{H}:{ }^{1} \mathrm{H}$ ratios in $\mathrm{H}_{2}$ gas generated from water samples using zinc catalyst. Rates of $\mathrm{CO}_{2}$ production were calculated from Eq. (2) in Nagy (1980), and water-flux rates from Eq. (4) in Nagy \& Costa (1980). Body-water volumes at the time of initial capture were estimated from the dilution space of ${ }^{18} \mathrm{O}$ upon injection (Nagy 1980). Water volumes at recapture were calculated as initial fractional water content times body mass at recapture.

Time budget. Both male and female Cape gannets share incubation and brooding, one adult usually remaining in attendance at the nest (Nelson 1978). On regular checks of nest sites the activity of injected, breeding adults was recorded as incubating (on or off nest) or brooding (on or off nest).

Field metabolic rates and feeding rates. FMRs were calculated from $\mathrm{CO}_{2}$ production, assuming an energy equivalent of $25.8 \mathrm{~J} \mathrm{ml}^{-1}$. This factor was calculated from the chemical composition of anchovies $172.7 \%$ water, $19.7 \%$ protein, $5.2 \%$ fat and $<0.5 \%$ carbohydrate) (South African Fishing Industry Research Institute 1980). Energy equivalents for fat and protein were taken from Schmidt-Nielsen (1979).

Rates of food consumption derived from metabolism measurements were calculated on the basis that anchovy dry mass contains $24.1 \mathrm{~kJ} \mathrm{~g}^{-1}$ of which $72.2 \%$ was assumed metabolizable (Cooper 1978). Thus, the metabolizable energy of anchovy was $4.89 \mathrm{~kJ} \mathrm{~g}^{-1}$ fresh mass. Rates of food consumption derived from waterinflux rates were calculated on the basis that anchovy contains $72.7 \% \mathrm{H}_{2} \mathrm{O}$. Metabolism of fish yields an additional $0.13 \mathrm{ml} \mathrm{g}^{-1}$ fresh mass, giving a total of $0.86 \mathrm{ml}$ $\mathrm{H}_{2} \mathrm{O} \mathrm{g}^{-1}$ fresh mass.

Basal metabolic rates (BMRs). Five adult non-breeding Cape gannets were collected from Malgas Island $\left(33^{\circ} 03^{\prime} \mathrm{S}, 17^{\circ} 55^{\prime} \mathrm{E}\right)$, some $100 \mathrm{~km}$ south of Lambert's Bay. Captive birds were fed daily at a rate at which they maintained capture mass ( $\pm 8 \%$ ). Measurements were conducted on post-absorbative birds, at least $12 \mathrm{~h}$ since the previous feed, in the laboratory using an open flow respiratory system. Dry, $\mathrm{CO}_{2}$-free air was pumped through a flow meter (Meterrate") before entering an airtight metabolic chamber (75 1) containing the gannet. Dry, $\mathrm{CO}_{2}$-free, outlet air was sampled off the main outlet pipe using an additional pump coupled to the sensor of an Ametek ${ }^{\circledR}$ S-3A/1 oxygen analyzer. The air 
temperature experienced by the bird was measured using a thermocouple and a Fluke thermometer. Temperatures in the metabolic chamber were maintained between 21 and $23^{\circ} \mathrm{C}$ by conducting measurements in a temperature-controlled room. Birds were allowed to acclimate in the metabolic chamber for $1 \frac{1 / 2}{2}$ before readings commenced. Daytime measurements were conducted between 07:00 and 15:00 h, while nighttime measurements were conducted between 20:00 and 02:00 h.

Flow rates were maintained around $31 \mathrm{~min}^{-1}$ and calibrated against a bubble meter (Levy 1964), at the beginning and conclusion of every run. Readings of fractional proportion of oxygen in outlet air were taken every $15 \mathrm{~min}$ until the period of lowest stable metabolism could be identified. Oxygen consumption was calculated from the equation of Hill (1972) for dry, $\mathrm{CO}_{2}$ free air converted to energy expenditure (assuming $\mathrm{RQ}=0.8,1 \mathrm{l} \mathrm{O} \mathrm{O}_{2}=20.087 \mathrm{~kJ}$ ) (Gessaman 1987). Birds were within the thermoneutral zone predicted from the appropriate equation in Kendeigh et al. (1977). Accordingly, we assumed the measurements we describe were a good estimate of BMR.

Aerodynamic properties. We measured wing span and wing area of 7 birds in order to calculate aspect ratio (wing $\operatorname{span}^{2} /$ wing area) and wing loading (mass in $\mathrm{kg} \times 9.81 \mathrm{~m} \mathrm{~s}^{-1} /$ wing area in $\mathrm{m}^{2}$ ). Measurements were made from tracing of wing-outline obtained by restraining gannets with their backs to the paper and wings fully extended. Estimates of wing area included body area between wings.

Statistics. Means are quoted as \pm 1 standard deviation. Two-tailed $t$-tests (homogeneous variances) and Mann-Whitney $U$-tests (heterogenous variances) were used to asses significance of differences between means. FMRs and water influx rates of gannets while on and off their nests were estimated by least squares regression analysis, coupled with analysis of covariance to detect significant differences between correlations. Probability values for regressions were calculated using $F$-tests for significance of the regression.

\section{RESULTS}

\section{Body mass, mass change and body water}

The mean body mass of the 11 incubating adults $(2690 \pm 110 \mathrm{~g})$ was significantly greater $(t=3.70, \mathrm{df}=$ $19, \mathrm{p}<0.005)$ than that of the 10 brooding adults $(2460$ $\pm 170 \mathrm{~g}$ ) we studied. Although incubating and brooding adults tended to lose body mass during the DLW measurement intervals (average mass loses of 1.3 and $2.9 \%$ of body mass $\mathrm{d}^{-1}$, respectively, during average measurement periods of 2.17 and $1.93 \mathrm{~d}$ respectively), these rates of body mass change were not significantly different from zero change (body mass maintenance), judging by the inclusion of zero within the $95 \%$ confidence limits of both mean values. Chicks (mean mass $1430 \pm 540 \mathrm{~g}, \mathrm{n}=6$ ) gained body mass at a statistically significant rate $\left(9.3 \pm 8.2 \% \mathrm{~d}^{-1}, 95 \% \mathrm{CI}=0.6\right.$ to 20.0$)$ during the measurement period (1.04 $\pm 0.32 \mathrm{~d})$.

Total body water, as a percent of body mass, was significantly lower in incubating adults $(66.3 \pm 2.1 \%$, $\mathrm{n}=13)$ than the brooding adults $(71.0 \pm 3.9 \%, \mathrm{n}=6)$ $(U=66, \mathrm{df}=17, \mathrm{p}<0.01)$. The water content of chicks $(71.7 \pm 2.1 \%, \mathrm{n}=3)$ was similar to that of brooding adults.

\section{Field metabolic rate}

Rates of $\mathrm{CO}_{2}$ production were much lower when adult gannets were at the nest than when they were away at sea. Regressions of $\mathrm{CO}_{2}$ production on percent of time off the nest for incubating adults and for brooding adults were statistically significant. However, analysis of covariance (ANCOVA) indicated that the separate regressions did not differ in either slope or intercept, so data were pooled and a single regression was calculated (Fig. 1). This relationship is highly sig-

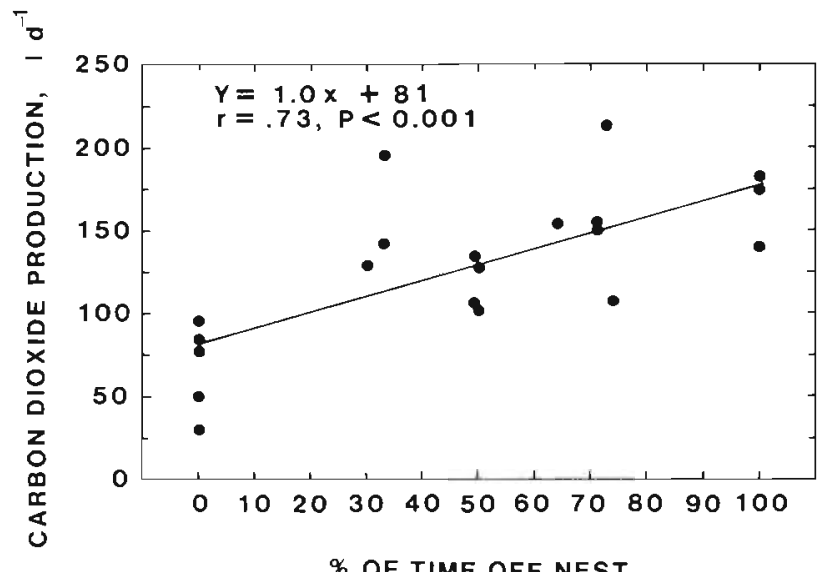

\% OF TIME OFF NEST

Fig. 1. Morus capensis. Carbon dioxide production rate of breeding Cape gannets as a function of the relative proportion of time off nest to the total sampling period

nificant $\left(F_{(1,19)}=22.2, \mathrm{p}<0.001\right)$, and is described by the equation: Litres $\mathrm{CO}_{2} \mathrm{~d}^{-1}=1.0$ ( $\%$ time off nest) + $81(r=0.73$, standard error of slope $=0.21$, SE of $y$ intercept $=12$ )

The $y$-intercept ( $0 \%$ time off nest) of this regression should represent the rate of $\mathrm{CO}_{2}$ production of gannets while on the nest. This value is $81 \mathrm{lCO}_{2} \mathrm{~d}^{-1}(95 \%$ confidence interval of the prediction $\pm 74 \mathrm{lCO}_{2} \mathrm{~d}^{-1}$ ), which is equivalent to an FMR of $2090 \mathrm{~kJ} \mathrm{~d}^{-1}(24.2 \mathrm{~W}$ ). A Cape gannet off the nest $100 \%$ of the time would be expected to produce $181 \mathrm{l} \mathrm{CO}_{2} \mathrm{~d}^{-1}$ (95\% of the predic- 
Table 1. Morus capensis. Energy expenditure of free ranging, breeding Cape gannets, and comparisons with basal metabolic rates and with energy expenditures of northern gannets $M$. bassanus

\begin{tabular}{|c|c|c|c|c|c|c|}
\hline & $\begin{array}{c}\text { FMR } \\
\left(k J d^{-1}\right)\end{array}$ & $\begin{array}{c}\text { BMR } \\
\left(k J d^{-1}\right)\end{array}$ & $\begin{array}{c}\text { Ratio } \\
\text { FMR/BMR }\end{array}$ & $\begin{array}{c}\text { Ratio } \\
\text { At-sea FMR/ } \\
\text { nest FMR }\end{array}$ & $\begin{array}{l}\text { Predicted FMR } \\
\qquad\left(k J d^{-1}\right)\end{array}$ & $\begin{array}{c}\text { Ratio } \\
\text { Meas. FMR/ } \\
\text { Pred. FMR }\end{array}$ \\
\hline \multicolumn{7}{|c|}{ Cape gannet $(2.58 \mathrm{~kg})$} \\
\hline \multicolumn{7}{|c|}{ Breeding adults } \\
\hline On nest & 2090 & 718 & 2.9 & & & \\
\hline Off nest & 4670 & 718 & 6.5 & 2.2 & & \\
\hline Overall & 3380 & 718 & 4.7 & & 2020 & 1.7 \\
\hline \multicolumn{7}{|c|}{ Northern gannet ${ }^{\mathrm{b}}(3.21 \mathrm{~kg})$} \\
\hline \multicolumn{7}{|c|}{ Breeding adults } \\
\hline On nest & 3452 & 742 & 4.7 & & & \\
\hline Off nest & 6000 & 742 & 8.1 & 1.7 & & \\
\hline Overall & 4865 & 742 & 6.6 & & 2356 & 2.1 \\
\hline \multicolumn{7}{|c|}{ a From Nagy (1987), FMR $=8.01 \mathrm{M}^{0704}(\mathrm{M}=$ body mass in $\mathrm{g})$} \\
\hline
\end{tabular}

tion $\pm 90 \mathrm{l} \mathrm{CO}_{2} \mathrm{~d}^{-1}$ ), which is equivalent to $4670 \mathrm{~kJ} \mathrm{~d}^{-1}$ $(54.1 \mathrm{~W})$. Because the breeding adults we studied spent about half their time on the nest and half off the nest, we estimated their overall FMR as the predicted $\mathrm{CO}_{2}$ production for $50 \%$ of the time off the nest: $1311 \mathrm{CO}_{2}$ $\mathrm{d}^{-1}\left(95 \% \mathrm{CI}\right.$ of the prediction $\left.\pm 72 \mathrm{lCO}_{2} \mathrm{~d}^{-1}\right)$. This is equivalent to $3380 \mathrm{~kJ} \mathrm{~d}^{-1}(39.1 \mathrm{~W}$ ) (Table 1 ).

Mass of chicks ranged from 850 to $2210 \mathrm{~g}$. Correlation coefficients of regressions of log metabolism vs log body mass and log mass specific metabolism only approached significance $(0.1>p>0.05)$. On average, chicks produced $49 \pm 10 \mathrm{l} \mathrm{CO}_{2} \mathrm{~d}^{-1}$, which is equivalent to $1264 \mathrm{~kJ} \mathrm{~d}^{-1}(14.6 \mathrm{~W})$ or $933.1 \mathrm{~kJ} \mathrm{~kg}^{-1} \mathrm{~d}^{-1}(10.8 \mathrm{~W}$ $\mathrm{kg}^{-1}$ ).

\section{Water flux rate}

Paired $t$-tests comparing water influx rates with water efflux rates of incubating and brooding gannets revealed no significant differences within either group as expected for animals maintaining water balance. As with $\mathrm{CO}_{2}$ production, there were statistically significant correlations between water influx rates and \% time off the nest for both incubating and brooding gannets. ANCOVA indicated no significant difference between the 2 regressions, so the data were pooled, and the overall regression was calculated. This regression (Fig. 2) is described by the equation: $\mathrm{ml} \mathrm{H}_{2} \mathrm{O}$ influx $\mathrm{d}^{-1}=4.5$ $(\%$ time off nest $)+161(\mathrm{r}=0.75, \mathrm{SE}$ of slope $=0.9, \mathrm{SE}$ of intercept $=55)$. The predicted water influx rate for $50 \%$ of time off the nest, as an estimate of overall water influx rate in breeding Cape gannets, is $336 \mathrm{ml} \mathrm{d}^{-1}$ $\left(95 \% \mathrm{Cl}\right.$ of prediction $\left.=312 \mathrm{ml} \mathrm{d}^{-1}\right)$. The water influx rates of chicks (average $=273 \pm 98 \mathrm{ml} \mathrm{d}^{-1}$ ) also did not differ significantly (paired $t$-test, $\mathrm{p}>0.05$ ) from their water efflux rates (average $=177 \pm 137 \mathrm{ml} \mathrm{d}^{-1}$ ).

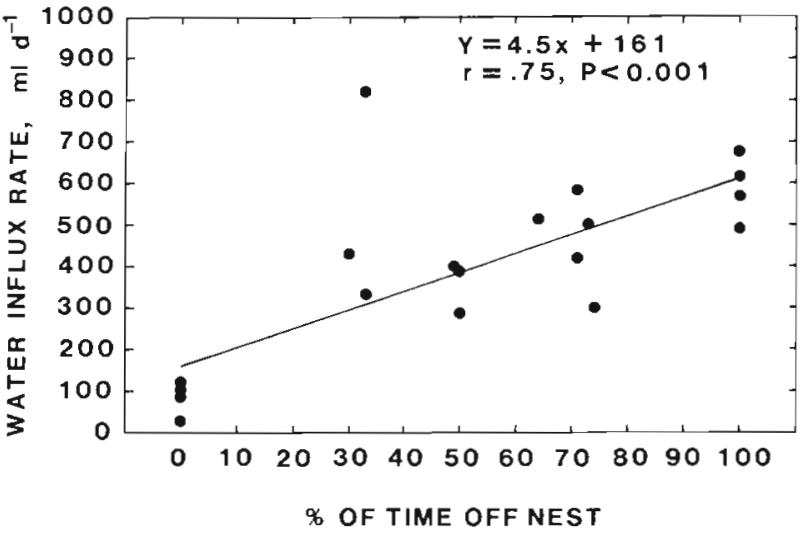

Fig. 2. Morus capensis. Water influx rate of breeding Cape gannets as a function of the relative proportion of time off nest to the total sampling period

\section{Basal metabolic rates}

BMRs of Cape gannets averaged $323 \pm 15 \mathrm{~kJ} \mathrm{~kg}^{-1}$ $\mathrm{d}^{\mathrm{i}}(\mathrm{n}=5$, mean mass $=2.66 \pm 0.16 \mathrm{~kg})$ or $856 \pm 42 \mathrm{~kJ}$ $\mathrm{d}^{-1}$ during the day, significantly different from the 278 $\pm 34 \mathrm{~kJ} \mathrm{~kg}^{-1} \mathrm{~d}^{-1}(\mathrm{n}=5$, mean mass $2.62 \pm 0.17 \mathrm{~kg})$ or $731 \pm 107 \mathrm{~kJ} \mathrm{~d}^{-1}$ measured at night $(t=2.68, \mathrm{df}=8$, $\mathrm{p}<0.05)$.

\section{Aerodynamic properties}

Seven Cape gannets of average mass $2757 \pm 169 \mathrm{~g}$ had a wing span of $173 \pm 8 \mathrm{~cm}$ and a wing area, including body area between wings, of $2429 \pm$ $169 \mathrm{~cm}^{2}$. Calculated wing loading and aspect ratios averaged $111 \mathrm{~N} \mathrm{~m}^{-2}$ and 12.5 , respectively. 


\section{DISCUSSION}

\section{Metabolic rates}

Absolute at-sea metabolic rates of Cape gannets are high compared to measurements for most other seabirds, being $143 \%$ and $34 \%$ higher than those predicted for seabirds using mainly gliding $(n=5)$ and non-gliding flight $(\mathrm{n}=10)$, respectively (values predicted from equations in Table 4 of Birt-Friesen et al. 1989). In contrast, mass-specific at-sea metabolic rates of Cape gannets were only $3 \%$ lower than those of congeneric northern gannets $(20 \%$ heavier than Morus capensis). Compared on BMR standard basis, at-sea metabolic rates of Cape and northern gannets were 6.5 and $8.1 \times$ BMR, respectively. The particularly high value for the latter species reflects their relatively low basal metabolic rates but high at-sea metabolism compared to Cape gannets.

Pennycuick (1989) has demonstrated that power requirements for actual flight in birds scale at a slope steeper than basal metabolism and, consequently, interspecific comparisons of potential flight costs based on multiples of BMR are inappropriate. However, this is not the case for the slope of the regression of at-sea FMR to body mass of seabirds (cf. Ellis 1984, BirtFriesen et al. 1989). That the relationships between power requirements for flight and $\mathrm{BMR}$ and between FMR and BMR are different may be a consequence of FMR being an integrated value of actual flight costs and other activities at sea and of the fact that, in general, large bird species make less use of flapping flight than small species.

Aspect ratios of Cape and northern gannets are similar to those of albatrosses, reflecting their almost indistinguishable wing shapes (Pennycuick 1987a, this study). However, wing loading values of gannets are higher than similarly sized albatrosses. This coupled with the propensity of gannets to make relatively less use of dynamic soaring and more use of flap-gliding than albatrosses (Pennycuick 1987b) may account for their relatively high at-sea metabolic rates. Such costs may be further increased by plunge-dive foraging. This technique involves incipent underwater flapping of wings (Nelson 1978, Pennycuick 1987a) and, in addition, requires gannets to get airborne from the seasurface with prey loads that for Cape gannets, at least, average $13 \%$ but may be up to $25 \%$ of total body mass (N. J. Adams unpubl. data).

Birt-Friesen et al. (1989) demonstrated that the FMR of northern gannets increased with increased flying time. Therefore, the absence of significant differences in the slope and intercept of regressions of $\mathrm{CO}_{2}$ production on percent of time off nest for incubating and brooding adults suggests Cape gannets attending chicks were not flying for an appreciably greater proportion of time at sea than those birds attending eggs. This was in spite of the need to collect additional food to feed chicks. However, in the absence of activity data such a conclusion must remain tentative.

Obst et al. (1987) argued that brooding was more costly than incubation. We were unable to distinguish any differences in the energy costs of these 2 activities. Cost of nest attendance by Cape gannets was $44 \%$ that of FMR at sea $(2.9 \times \mathrm{BMR}), 14 \%$ lower than the $58 \%$ determined for northern gannets $(4.65 \times \mathrm{BMR})$. The relatively high cost of nest attendance of northern gannets was attributed to the high thermoregulatory costs in the cold, windy and wet environment off Newfoundland, Canada and very aggressive nest defence (BirtFriesen et al. 1989). Cape gannets also breed in densely packed colonies characterized by high levels of intraspecific aggression, but at latitudes and in the season with high levels of insolation. However, at least some additional thermoregulatory costs are likely to be incurred by Cape gannets attempting to reduce heat loads during the frequent sunny days and the reason for the large difference between metabolic rates at nest sites is not readily apparent.

Overall metabolic rates of Cape gannets, assuming birds spent half their time at the nest and half away at sea, were estimated at $3380 \mathrm{~kJ} \mathrm{~d}^{-1}, 67 \%$ higher than predicted from the general equation for seabirds (Nagy 1987) but within $3 \%$ of that predicted for high latitude seabirds using flapping flight (predicted from Eq. (6), Birt-Friesen et al. 1989]. Values for northern gannets were 106 and $19 \%$ higher, respectively. The particularly high values for northern gannets partly reflect their relatively high energy costs while at the nest. When expressed as a multiple of at-nest costs, overall FMRs of northern and Cape gannets were 1.4 and 1.6 respectively, within the range (1.3 to 3.2$)$ determined for other seabirds (data from Birt-Friesen 1989).

Overall FMR of Cape gannets was $4.7 \times$ BMR. This value and the overall FMR of northern gannets of $6.6 \times$ BMR exceed $4 \times B M R$, a value suggested to be the maximum sustainable metabolic rate for birds (Drent \& Daan 1980). In contrast to many pelagic seabirds, the period of continuous adult attendance at the nest extends throughout most of chick-rearing for gannets. The potential foraging time of each adult is halved and any accompanying energy constraints operating on the adult, potentially compounded by these high metabolic rates, will be maintained throughout chick rearing. The ability to maintain these high metabolic rates may be dependent on these birds exploiting productive areas of ocean with large populations of surface shoaling fish. We concur with Birt-Friesen et al. (1989) that additional measurements of FMR of seabirds coupled with activity 
data are required to elucidate the energetic consequences of different flight modes. Studies of the energy budgets of tropical boobies should prove particularly enlightening

\section{Foraging efficiency}

Nagy et al. (1984) defined the foraging efficiency of an animal as the ratio of metabolizable energy gained while foraging to the energy used while foraging. This index does not account for food energy fed to chicks and consequently underestimates foraging efficiency. Assuming a $48 \mathrm{~h}$ at-sea/nest attendance cycle for breeding Cape gannets, total energy consumption is $6760 \mathrm{~kJ}$. During an at-sea period of $24 \mathrm{~h}$ Cape gannets utilize $4670 \mathrm{~kJ}$. Foraging efficiency is then 1.45. This value is similar to the 1.4 calculated for breeding greyheaded albatrosses Diomedea chrysostoma (Costa \& Prince 1987), but lower than that of breeding jackass penguins Spheniscus demersus (2.1) (Nagy et al. 1984). That the foraging efficiency of non-breeding jackass penguins was 6.8 indicates foraging efficiencies may vary considerably.

Therefore, given the large differences in locomotory and foraging techniques among the 3 species above, this similarity of the values is striking. This lends further support to the suggestion that birds with costly foraging techniques are restricted to breeding at sites adjacent to areas of high food availability (Furness \& Monaghan 1987). In the Benguela upwelling region such conditions arise from the presence of large biomass of migratory pelagic fish confined largely to coastal waters (Crawford et al. 1987)

\section{Energy requirements of chicks}

The FMR of Cape gannet chicks of estimated age 19 to $45 \mathrm{~d}$ ranged from 877 to $1496 \mathrm{~kJ} \mathrm{~d}^{-1}$ for chicks of $850 \mathrm{~g}$ and $2210 \mathrm{~g}$ respectively. This measurement includes the energy costs of maintenance, thermoregulation, synthesis costs associated with growth of new tissue and any activity costs. It does not include the chemical potential energy required for growth which may be calculated from the mass increase of the chick and knowledge of the energy content of chick tissue. The mean daily increase in chick mass during this period of rapid growth was $133 \mathrm{~g} \mathrm{~d}^{-1}$. Energy density of Cape gannet chicks increases linearly with age ( $R$. Navarro pers. comm.) in a similar way to that of northern gannet chicks (Montevecchi et al. 1984) and for chicks of 19 and $45 \mathrm{~d}$ was estimated at 5.9 and $7.9 \mathrm{~kJ}$ $\mathrm{g}^{-1}$, respectively. Therefore, the rate of chemical potential energy accumulation in body tissue of Cape gannet chicks ranged between 785 and $1051 \mathrm{~kJ} \mathrm{~d}^{-1}$. Total energy requirements during the period of growth would be between 1662 and $2547 \mathrm{~kJ} \mathrm{~d}^{-1}$ of metaboliz able energy.

This rate of energy accumulation represents 47 and $41 \%$ respectively of the total metabolizable energy utilized by the Cape gannet chicks of 19 and $45 \mathrm{~d}$. Requirements of northern gannet chicks between 21 and $42 \mathrm{~d}$ averaged $1718 \mathrm{~kJ} \mathrm{~d}^{-1}$ of which approximately $43 \%$ was allocated to growth. Montevecchi et al. (1984) attributed most of the energy requirements of growth of northern gannet chicks over 3 wk of age to lipid accumulation. It is clear that Cape gannet chicks also accumulate such lipid reserves (R. Navarro pers. comm.).

\section{Feeding rates}

During December 1981 and January 1982 the diet of Cape gannets at Lambert's Bay consisted of 100 and $80 \%$ anchovy by mass respectively (Sea Fisheries Research Institute, Cape Town unpubl.). For the purposes of calculating feeding rates we assumed the diet was $100 \%$ anchovy for both months.

Because at least one adult Cape gannet is in attendance at the nest while breeding, the proportions of time allocated to on- and off-nest periods by an individual bird were in the ratio $1: 1$. Energy expenditure during incubation and chick rearing averages $3380 \mathrm{~kJ} \mathrm{~d}^{-1}$ (Table 1) which is equivalent to $691 \mathrm{~g}$ anchovy bird ${ }^{-1}$ $\mathrm{d}^{-1}$. Incubation and chick-rearing periods of Cape gannets are 44 and $97 \mathrm{~d}$ respectively. Food consumption over the lay-to-fledge period is then $97.4 \mathrm{~kg} \mathrm{bird}^{-1}$ or $194.8 \mathrm{~kg} \mathrm{pair}{ }^{-1}$ not including food delivered to chicks.

Food consumption rates may also be calculated from water-flux measurements. Predicted water-flux of breeding Cape gannets assuming $50 \%$ of the time is spent away from the nest is $336 \mathrm{ml} \mathrm{d}^{-1}$. If we assume that no water is directly ingested at sea and that all water is obtained from metabolism of food, then the estimated feeding rate of a breeding Cape gannet is $391 \mathrm{~g}$ anchovy bird ${ }^{-1} \mathrm{~d}^{-1}, 43 \%$ lower than estimated from energy calculations. This is a large discrepancy and suggests that labelled gannets may have been eating fish with a higher lipid content and less water than analyses suggest. In addition, if gannets were in negative energy balance, calculations of feeding rates from FMR should overestimate actual rates somewhat. Although rates of body mass change of breeding Cape gannets were not significantly different from zero over measurement periods of about $2 d$, the significantly lower body mass of brooding gannets in January 1982 compared to incubating adults in December 1981 suggest Cape gannets are in negative energy balance while breeding. The higher water content of brooding 
birds indicates adults were using body fat and becoming leaner through the season. Data from several doubly labelled water studies indicate this situation is common among breeding seabirds (see Birt-Friesen et al. 1989). Similar estimates of the metabolizable energy intake of northern gannets calculated from water-flux measurements were also lower than those estimated from FMR by $27 \%$ (Birt-Friesen et al. 1989). Because estimates of feeding rates from water-flux require more assumptions than those based on FMR (Nagy 1980 , Nagy \& Costa 1980), calculations of total food consumption have been based on FMR.

Assuming the average daily metabolizable energy required by Cape gannet chicks to meet the energy requirements of growth and maintenance are approximated by that of a chick at $45 \mathrm{~d}$ (about half way through the chick rearing period), the cost is $2547 \mathrm{~kJ} \mathrm{~d}^{-1}$. This is equivalent to a feeding rate of $521 \mathrm{~g} \mathrm{~d}^{-1}$ or $51 \mathrm{~kg}$ of anchovy during its $97 \mathrm{~d}$ chick rearing period. The average food intake of Cape gannet chicks hand-fed on anchovy to near satiation over $97 \mathrm{~d}$ was $426 \mathrm{~g} \mathrm{~d}^{-1}$, with food intake peaking at $587 \mathrm{~g} \mathrm{~d}^{-1}$ in chicks of 70 to $71 \mathrm{~d}$ (Cooper 1978). This suggests our approach may overestimate average intake. At $45 \mathrm{~d}$ chicks are growing rapidly yet are also approaching $67 \%$ of peak mass (Jarvis 1971), consequently both energy requirements for growth and maintenance are large and such a conclusion is not surprising. However, in the absence of a comprehensive data set we have no justification for adjusting our estimate.

Northern gannet chicks were estimated to consume only $24 \mathrm{~kg}$ of food over the $91 \mathrm{~d}$ nestling period, equivalent to $265 \mathrm{~g} \mathrm{~d}^{-1}$ (Montevecchi et al. 1984). The difference between this figure and that of Cape gannets is largely attributable to the higher energy value of food fed to northern gannet chicks (Montevecchi et al. 1984).

Total food requirements for a pair of Cape gannets raising a chick to fledging would be $195 \mathrm{~kg}$ for the adults and $51 \mathrm{~kg}$ for the chick, giving a total of $246 \mathrm{~kg}$ of fish over the $141 \mathrm{~d}$ breeding season. Based on the above measurements we can also estimate the total consumption of food by Cape gannets in the region.

There are 2 Cape gannet colonies off the southwestern coast of South Africa that lie within the area utilized by the purse-seine fishery (Berruti 1987). We assumed that birds were present in the fishing area throughout the year and that field metabolic rates measured for breeding gannets were representative of energy costs of adult birds throughout the year. Calculations based on such assumptions are likely to overestimate actual consumption but in the absence of any data we cannot quantify this at present. These data were combined with estimates of population sizes and diet composition (Berruti 1987) to calculate annual energy expenditure and food consumption (Tables $2 \& 3$ ). Total consumption was estimated at $23400 \mathrm{t}$ per annum, considerably higher than the $9500 \mathrm{t}$ estimated for the same population by Duffy et al. (1987). Duffy et al. (1987) based their estimate on an allometric equation which underestimated field metabolic rates, at least during breeding.

Comparison of our consumption estimate with fishery catches (Crawford et al. 1987) indicated that between 1980 and 1985, Cape gannets were consuming, on average, 16 and $3 \%$ of the total pilchard and anchovy catch (both restricted by quota), respectively. Acoustic surveys carried out in November 1984 and 1985 (Hampton 1987) suggested that the Cape anchovy spawner biomass (the most economically important of the pelagic fish species) was in the order of a million tonnes. Average annual gannet catch of anchovy was, therefore, only $0.9 \%$ of adult fish biomass. Consequently, in spite of our revised consumption figure which suggests gannets consume more than double that estimated by Duffy et al. (1987), only a small proportion of the annual production of anchovy is being removed by gannets. Cape gannets are one of the 3 major resident seabird consumers in the region and the conclusion of Duffy et al. (1987) that seabird consumption is relatively unimportant compared with that of other predators in the system appears still valid. It is

Table 2. Morus capensis. Estimated annual energy expenditure of Cape gannets in the southern Benguela upwelling system

\begin{tabular}{|c|c|c|c|c|c|}
\hline & Location & No. of birds & $\begin{array}{l}\text { No. of days } \\
\text { present }\end{array}$ & $\begin{array}{l}\text { Energy expenditure } \\
\qquad\left(\mathrm{kJ} \mathrm{d} \mathrm{d}^{-1}\right)\end{array}$ & $\begin{array}{l}\text { Total energy } \\
\text { expenditure }\left(\mathrm{kJ} \times 10^{9}\right)\end{array}$ \\
\hline \multirow[t]{2}{*}{ Breeding adults ${ }^{a}$} & Lambert's Bay & 18456 & 365 & 3380 & 22.8 \\
\hline & Malgas Island & 60018 & 365 & 3380 & 74.0 \\
\hline \multirow[t]{3}{*}{ Fledglings ${ }^{b}$} & Lambert's Bay & 4060 & 97 & 2547 & 1.0 \\
\hline & Malgas Island & 13203 & 97 & 2547 & 3.2 \\
\hline & & & & Total & 101.0 \\
\hline
\end{tabular}


Table 3. Morus capensis. Annual estimated food consumption of Cape gannets in the southern Benguela upwelling system

\begin{tabular}{|c|c|c|c|c|c|c|}
\hline \multirow[t]{2}{*}{ Prey species } & \multirow{2}{*}{$\begin{array}{l}\text { Metabolizable } \\
\text { energy content } \\
\qquad\left(\mathrm{kJ} \mathrm{g}^{-1}\right)\end{array}$} & \multicolumn{2}{|c|}{ Malgas Island } & \multicolumn{2}{|c|}{ Lambert's Bay } & \multirow{2}{*}{$\begin{array}{c}\text { Total } \\
\text { consumption } \\
(t)\end{array}$} \\
\hline & & $\%$ in diet ${ }^{b}$ & $\begin{array}{c}\text { Mass consumed } \\
\text { (t) }\end{array}$ & $\%$ in diet ${ }^{6}$ & $\begin{array}{c}\text { Mass consumed } \\
\text { (t) }\end{array}$ & \\
\hline Cape anchovy & 4.89 & 32.8 & 5940 & 63.2 & 3340 & 9280 \\
\hline Pilchard & 4.78 & 22.5 & 4070 & 7.2 & 380 & 4450 \\
\hline Saury & 2.91 & 7.7 & 1390 & 9.2 & 490 & 1880 \\
\hline Hake & 3.61 & 29.6 & 5360 & 4.8 & 240 & 5600 \\
\hline Other & 4.04 & 7.4 & 1340 & 15.6 & 820 & 2160 \\
\hline Total & & & 18100 & & 5270 & 23370 \\
\hline
\end{tabular}

now clear that there may be considerable short- and long-term natural variability in pelagic fish populations and their seabird predators (Duffy \& Siegfried 1987) and single estimates of total consumption, such as presented here, must be evaluated in this light.

Acknowledgements. We are grateful for financial support from the Benguela Ecology Programme, the University of Cape Town and Contract DE-AC03-76-SF00012 from the United States Department of Energy. The Marine Development Branch of the Sea Fisheries Research Institute allowed access to Bird Island. W. A. Montevecchi and V. L. Birt-Friesen commented extensively on a draft of this paper, and their suggestions did much to improve the manuscript. The Sea Fisheries Research Institute, Cape Town and R. A. Navarro kindly allowed access to their unpublished data.

\section{LITERATURE CITED}

Adams, N. J., Brown, C. R., Nagy, K. A. (1986). Energy expenditure of free-ranging wandering albatrosses Diomedea exulans. Physiol. Zool. 59: 583-591

Berruti, A. (1987). The use of Cape gannets Morus capensis in management of the purse-seine fishery of the Western Cape. Ph.D. thesis, University of Natal

Berruti, A., Colclough, J. (1987). Comparison of the abundance of pilchard in Cape gannet and commercial catches off the Western Cape, South Africa. S. Afr J. mar. Sci. 5: 863-871

Birt-Friesen, V L, Montevecchi, W. A., Caims, D. K., Macko, S. A. (1989). Activity-specific metabolic rates of free-living northern gannets and other seabirds. Ecology 70: 357-367

Cooper, J. (1978). Energetic requirements for growth and maintenance of the Cape gannet (Aves; Sulidae). Zool. Africana 13: 305-317

Cooper, J., Siegfried, W. R. (1976). Behavioural responses of young Cape gannets Sula capensis to high ambient temperatures. Mar. Behav. Physiol 3: 211-220

Costa, D. P., Prince, P. A. (1987). Foraging energetics of greyheaded albatrosses Diomedea chrysostoma at Bird Island, South Georgia. Ibis 129: 149-158

Crawford, R. J. M., Shannon, L. V., Pollock, D. E. (1987). The Benguela ecosystem. Part IV The major fish and invertebrate resources. Oceanogr. mar Biol. A. Rev. 25: $353-505$
Croxall, J. P. (1987). Conclusions. In: Croxall, J. P. (ed.) Seabirds: feeding ecology and role in marine ecosystems. Cambridge University Press, Cambridge, p. 369-381

Drent, R. H., Daan, S. (1980). The prudent parent: energetic adjustments in avian breeding. Ardea 68: 225-252

Duffy, D. C., Siegfried, W. R. (1987). Historical variations in the food consumption by breeding seabirds of the Humboldt and Benguela upwelling regions. In: Croxall, J. P. (ed.) Seabirds feeding ecology and role in marine ecosystems. Cambridge University Press, Cambridge, p. 327-346

Duffy, D. C., Siegfried, W. R., Jackson, S. (1987). Seabirds as consumers in the southern Benguela region S. Afr. J. mar. Sci. 5: 771-790

Ellis, H. I. (1984). Energetics of free-ranging seabirds. In: Whittow, G. C., Rahn, H. (eds.) Seabird energetics. Plenum Press, New York, p. 203-234

Furness, R. W., Cooper, J. (1982). Interactions between breeding seabirds and pelagic fish populations in the Southern Benguela region. Mar. Ecol. Prog. Ser 8: 243-250

Furness, R. W., Monoghan, P. (1987). Seabird ecology. Chapmans and Hall, New York

Gabrielsen, G. W., Mehlum, F., Nagy, K. A. (1987). Daily energy expenditure and energy utilization of free ranging black-legged kittiwakes. Condor 89: 126-132

Gessaman, J. A. (1987). Energetics. In: Giron Pendleton, B. A., Millsap, B. A., Cline, K. W., Bird, D. M. (eds.) Raptor management techniques manual. National Wildlife Federation, Washington D.C., p. $289-320$

Hampton, I. (1987). Acoustic study on the abundance and distribution of anchovy spawners and recruits in South African waters. S. Afr. J. mar. Sci. 5: 901-917

Hill, R. N. (1972). Determination of oxygen consumption by use of the paramagnetic oxygen analyzer. J. appl. Physiol. 33: 261-263

Jarvis, M. J. F. (1971). Ethology and ecology of the South African Gannet Sula capensis. Ph.D. thesis, University of Cape Town

Kendeigh, S. C., Dol'nik, V. R., Gavrilov, V M. (1977). Avian energetics. in: Pinowski, J., Kendeigh, S. C. (eds.) Granivorous birds in ecosystems. Cambridge University Press, Cambridge, p. 127-204

Levy, A. (1964). The accuracy of the bubble meter method for gas flow measurements. J. Sci. Instrum. 41. 449-453

Lifson, N, McClintock, R. (1966). The theory of the use of the tumover rates of body water for measuring energy and material balance. $J$. theor Biol. 12: 46-74 
Montevecchi, W. A., Ricklefs, R. E., Kirkham, I. A., Gabaldon, $D$. (1984). Growth energetics of nestling northern gannets (Sula bassanus). Auk 101, 334-341

Nagy, K. A. (1980). $\mathrm{CO}_{2}$ production in animals: analysis of potential errors in the doubly labeled water method. Am. J. Physiol. 238: R466-R473

Nagy, K. A. (1987). Field metabolic rates and food requirements scaling in mammals and birds. Ecol. Monogr 57 $111-128$

Nagy, K. A., Costa, C. P. (1980). Water flux in animals: analysis of potential errors in the tritiated water method. Am. J. Physiol. 238: R454-R465

Nagy, K. A., Siegfried, W. R., Wilson, R. P. (1984). Energy utilization by free ranging Jackass Penguins Spheniscus demersus. Ecology 65: 1648-1655

Nelson, J. B. (1978). The sulidae. Oxford University Press, Oxford

Obst, B. S., Nagy, K. A., Ricklefs, R. E. (1987). Energy utilization by Wilson's Storm-Petrel (Oceanites oceanicus). Physiol. Zool. 60: 200-210

Pennycuick, C. J. (1987a). Flight of auks (alcidae) and other northern seabirds compared with southern Procellariiformes: ornithodolite observations. J. exp. Biol. 128: 335-347

This article was submitted to the editor
Pennycuick, C. J. (1987b). Flight of seabirds. In: Croxall, J. P. (ed) Seabirds: feeding ecology and role in marine ecosystems. Cambridge University Press, Cambridge

Pennycuick, C. J. (1989). Bird flight performance. A practical calculation manual. Oxford University Press, New York

Pettit, T N., Nagy, K. A., Ellis, H. I., Whittow, G. C. (1988) Incubation energetics of the Laysan albatross. Oecologia $74: 546-550$

Roby, D. D., Ricklefs, R. W. (1986). Energy expenditure in least auklets and diving petrels during the chick rearing period. Physiol. Zool. 59: 661-678

South African Fishing Industry Research Institute (1980). Thirty-fourth annual report of the director, JanuaryDecember 1980. University of Cape Town

Schmidt-Nielsen, K. (1979). Animal physiology. Adaptations and environment. Cambridge University Press, Cambridge

Tucker, V. A. (1973). Bird metabolism during flight: evaluation of a theory. J. exp. Biol. 58: 689-709

Wiens, J. A., Scott, J. M. (1975). Model estimation of energy flow in Oregon coastal seabird populations. Condor 77 : $439-452$

Manuscript first received: December 18, 1989

Revised version accepted: November 6, 1990 